\title{
Rancang Bangun Fixture Perakitan Runner dan Casing Turbin Cross Flow
}

\author{
Muas M. ${ }^{1^{*}}$, Baso Nasrullah ${ }^{2}$, Herdiman $^{3}$ dan Ahsan Muslimin ${ }^{4}$ \\ 1,2,3,4 Jurusan Teknik Mesin, Politeknik Negeri Ujung Pandang, Makassar 90245, Indonesia \\ "muas@poliupg.ac.id
}

\begin{abstract}
One of the important turbine components to consider in its manufacture is the runner and turbine casing components. The large number of parts that must be welded and the use of tools that do not meet functional requirements causes some problems during the assembly process, the problem is due to the difficulty of obtaining straightness between the disc and runner shaft where both components occur run-out deviations that exceed the allowable tolerance, as well as casing component assembly where almost all of the joints undergo a simple welding process and use of aids causing a very large dimension deviation from the specified tolerance. The use of very simple tools will cause difficulties in controlling the dimensions or uniformity of the shape during the production process. For this reason, a fixture that is suitable for the runner and turbine casing is needed to get the assembly process that matches the specified geometry tolerance. This research makes the fixture design to be used in runner assembly and turbine casing assembly with the assembly method is carried out in stages. The design is done in five stages, namely the stage of problem statement, the stage of making needs analysis, the stage of gathering information and ideas, the stage of making temporary designs and the stage of making the final draft. Fixture manufacturing is done in two stages, namely ordering materials (purchasing materials) and making fixture components. The final result of making runners and casings using a fixture is able to reduce the aberration in the runner and turbine casing components by producing run-outs at runners of $2.0 \mathrm{~mm}$ and the straightness of the casing straightness of $1.6 \mathrm{~mm}$, but have not been able to achieve deviations from the targeted one mm.
\end{abstract}

Keywords: Assembly; Fixture; Runner; Casing; Geometry Tolerance; Design

\begin{abstract}
Abstrak: Salah satu komponen turbin yang penting untuk diperhatikan dalam pembuatanya adalah komponen runner dan casing turbin. Banyaknya bagian yang harus dilas dan penggunaan alat bantu yang belum memenuhi syarat fungsional menyebabkan terjadinya beberapa masalah ketika proses perakitan, permasalahan tersebut disebabkan sulitnya mendapatkan ketegak lurusan antara piringan dan poros runner dimana pada kedua komponen tersebut terjadi penyimpangan runout yang melebihi toleransi yang diijinkan, seperti halnya perakitan komponen casing yang dimana hampir seluruh sambungan mengalami proses pengelasan dan penggunaan alat bantu yang sederhana sehingga menyebabkan penyimpangan dimensi yang sangat besar dari toleransi yang ditentukan. Penggunaan alat bantu yang sangat sederhana akan menimbulkan kesulitan dalam mengontrol dimensi atau keseragaman bentuk selama berlangsungnya proses produksi. Untuk itu dibutuhkan fixture yang cocok untuk proses perakitan runner maupun casing turbin untuk mendapatkan proses perakitan yang sesuai toleransi geometri yang ditentukan. Penelitian ini membuat rancang bangun fixture untuk digunakan dalam perakitan runner dan perakitan casing turbin dengan metode perakitan dilakukan secara bertahap. Perancangan dilakukan dalam lima tahap yaitu tahap pernyataan persoalan, tahap pembuatan analisa kebutuhan, tahap pengumpulan informasi dan gagasan, tahap pembuatan rancangan sementara dan tahap pembuatan rancangan akhir. Sedangkan pembuatan fixture dilakukan dalam dua tahap yaitu pemesanan material (pembelian material) dan pembuatan komponen fixture. Hasil akhir dari pembuatan runner dan casing dengan menggunakan fixture adalah mampu menurunkan penyimpangan pada komponen runner dan casing turbin dengan menghasilkan runout pada runner sebesar 2.0 $\mathrm{mm}$ dan ketegak lurusan casing sebesar $1.6 \mathrm{~mm}$, tetapi belum mampu mencapai penyimpangan dari yang ditargetkan yaitu $1 \mathrm{~mm}$.
\end{abstract}

Kata kunci: Assembly, Fixture, Runner, Casing, Toleransi Geometri, Perancangan

\section{PENDAHULUAN}

Salah satu kegiatan praktikum mahasiswa Program Studi Teknik Manufaktur angkatan 2011 pada semester ganjil 2014/2015 adalah membuat turbin air tipe cross flow kapasitas 10-20 kW dengan diameter runner $20 \mathrm{~cm}$, seperti yang terlihat pada gambar 1.1 Pembuatan turbin air cross flow tersebut dilakukan melalui beberapa proses permesinan konvensional seperti proses las listrik, proses bubut, 
proses drilling, proses milling dan lain-lain. Secara umum, tahapan pembuatan turbin air tersebut terdiri atas 2 (dua) tahapan, yakni pembuatan dan perakitan komponen turbin.

Pembuatan komponen turbin merupakan fase yang menitikberatkan pada toleransi bentuk yang harus dipenuhi pada sebuah elemen tunggal dengan memperhatikan sifat komponen yang diberi toleransi, seperti kelurusan, kedataran, kebulatan, dsb. Sedangkan perakitan komponen turbin merupakan fase yang menitikberatkan pada toleransi orientasi, toleransi lokasi, dan toleransi putar, yang harus dipenuhi pada sebuah elemen-elemen yang berhubungan. Elemen-elemen yang berhubungan tersebut harus memperhatikan sifat-sifatnya terhadap toleransi yang diberikan seperti toleransi kesejajaran, toleransi ketegaklurusan, dan sebagainya.

Salah satu komponen turbin yang penting diperhatikan dalam pembuatannya adalah runner turbin. Proses pembuatan runner turbin dimulai dengan pembuatan poros, piringan (disc) dan sudu-sudu runner. Kemudian dilanjutkan dengan proses perakitan (assembly) pada ketiga komponen tersebut. Banyaknya bagian yang harus di las dan penggunaan alat bantu yang belum memenuhi syarat fungsional mengakibatkan terjadinya beberapa masalah ketika proses perakitan runner tersebut dilakukan. Permasalahan tersebut disebabkan sulitnya mendapatkan ketegaklurusan antara piringan dan poros runner, dimana pada kedua komponen tersebut terjadi penyimpangan putar (runout) yang besar sehingga dibutuhkan proses permesinan lagi. Permasalahan lain adalah sulitnya mendapatkan dimensi yang seragam antar produk dan perakitannya pun membutuhkan dua atau lebih orang untuk dilibatkan dalam pengerjaannya.

Komponen lain yang harus diperhatikan adalah rumah runner (casing turbin). Proses pembuatan rumah runner (casing turbin) dimulai dengan pembuatan komponen-komponen dengan permesinan yang konvensional yang kemudian dilanjutkan dengan proses perakitan. Proses perakitan rumah runner/casing turbin tersebut mengalami proses pengelasan di hampir seluruh sambungan antar komponen dan proses perakitanya pun menggunakan alat bantu yang sederhana sehingga menyebabkan terjadi beberapa masalah dalam proses perakitannya.

Masalah yang terjadi ketika proses perakitan tersebut ialah sangat sulit mencari ketegaklurusan dinding-dinding casing sehingga mengakibatkan ketidak sesuaian dimensi casing yang diinginkan serta ketidak seragaman dimensi antara casing turbin satu dengan yang lainya dimana setelah dilakukan pengukuran jarak anatar dinding terjadi penyimpangan dimensi yang besar yaitu 3-4 mm dari ukuran dasar.

Pembuatan turbin dengan alat bantu yang sangat sederhana akan menimbulkan kesulitan dalam mengontrol dimensi atau keseragaman bentuk selama berlangsungnya proses produksi, serta membutuhkan biaya tinggi dan waktu yang lama untuk membuatnya di sebabkan kesulitan dalam proses perakitanya.

Untuk mendapatkan produk yang seragam dan sesuai dengan ukuran dasar maka perlu di lakukan proses perakitan (assembly) yang akurat dan presisi dengan sistem fixture guna menghindari kesalahan-kesalahan dalam perakitan komponen-komponen tersebut untuk memperoleh posisi-posisi komponen runner dan casing turbin seragam serta untuk menurunkan penyimpangan yang terjadi dengan target penyimpangan geometri sebesar $1.0 \mathrm{~mm}$.

\section{METODE PENELITIAN}

\section{A. Metode Penelitian}

Kegiatan penelitian dilaksanakan di jurusan Teknik Mesin Politeknik Negeri Ujung Pandang mulai dari tahap persiapan dan observasi, perancangan konsep, proses pembuatan fixture runner dan casing, kemudian pengujian fixture perakitan runner dan casing turbin, dengan tujuan untuk mengetahui efisiensi penyimpangan yang terjadi pada runner dan casing turbin.Penelitian ini dimulai bulan pebruari 2015 sampai bulan September 2015. 
Perancangan konsep fixture dibuat untuk dilakukan pemilihan konsep rancangan yang terbaik sesuai dengan kriteria yang ingin di capai. Tahapan pertama yang dikukan yaitu tahap pernyataan persoalan, tahap ini di jelaskan mengenai permasalahan yang ada berkaitan dengan proses perakitan runner dan casing turbin cross flow.

Berangkat dari masalah sistem turbin pada umumnya adalah masalah penurunan efisiensi dan berkurangnya umur material selama atau pada saat turbin air dioperasikan. Kedua hal ini timbul karena beberapa hal berikut ini: Ada kerugian akibat penurunan kecepatan putar runner yang diakibatkan oleh gesekan yang terjadi pada permukaan antar komponen saat melakukan pergerakan, adanya ketidak seimbangan massa pada komponen berputar yang menimbulkan getaran yang dapat mengakibatkan kegegelan-kegegalan akibat material lelah.

Tabel 1. Pernyataan persoalan

\begin{tabular}{|l|l|l|}
\hline No & \multicolumn{1}{|c|}{ Runner } & \multicolumn{1}{|c|}{ Casing } \\
\hline 1 & $\begin{array}{l}\text { Sulit mendapatkan ketegaklurusan antara } \\
\text { piringan dan poros. }\end{array}$ & $\begin{array}{l}\text { Sulit mencari ketegak lurusan dinding-dinding } \\
\text { casing yang mengakibatkan ketidak sejajaran } \\
\text { dan ketidak sesuaian dimensi antar dinding. }\end{array}$ \\
\hline 2 & $\begin{array}{l}\text { Sulit mendapatkan dimensi yang seragam } \\
\text { antar produk. }\end{array}$ & $\begin{array}{l}\text { Ketidak seragaman dimensi antar casing turbin } \\
\text { satu dengan yang lainya. }\end{array}$ \\
\hline 3 & $\begin{array}{l}\text { Membutuhkan 2 orang atau lebih dalam } \\
\text { proses perkaitanya }\end{array}$ & $\begin{array}{l}\text { Terjadi penyimpangan dimensi yang besar yaitu } \\
\text { 3-4 mm dari ukuran dasar. }\end{array}$ \\
\hline
\end{tabular}

Dari penjabaran maslah di atas, hasil yang di dapat adalah daftar tuntutan yang harus dan perlu dipenuhi dalam perancangan dimana hal ini merupakan gambaran keinginan dari kosumen, baik dari perakitan runner maupun casing turbin cross-flow, yaitu:

Tabel 2 Daftar Tuntutan Produk

\begin{tabular}{|c|c|}
\hline Kriteria demands & Kriteria wishes \\
\hline $\begin{array}{l}\text { a. Mampu menghasilkan dimensi produk yang } \\
\text { seragam } \\
\text { b. Mampu menghasilkan ketegaklurusan } \\
\text { sambungan produk yang sesuai toleransi } \\
\text { c. Pemasangan dan pengoprasianya mudah }\end{array}$ & $\begin{array}{l}\text { a. Mudah dalam perawatan dan perbaikan } \\
\text { b. Komponen yang digunakan mudah di dapat di } \\
\text { pasaran } \\
\text { c. Tidak membutuhkan tempat khusus } \\
\text { d. Harga terjangkau } \\
\text { e. Memiliki kekuatan yang baik } \\
\text { f. Memiliki umur pakai yang panjang }\end{array}$ \\
\hline
\end{tabular}

Dari penjabaran daftar tuntutan produk yang harus di hasilkan maka dibuatlah Batasan geometri yang ditargetkan untuk proses runout pada runner dan ketgak lurusan pada casing adalah $1 \mathrm{~mm}$. 

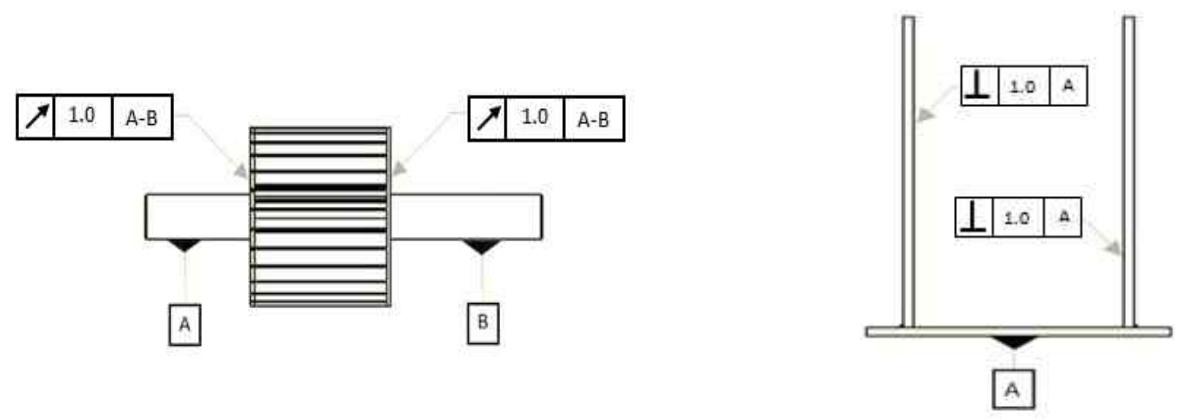

Gambar 1. Target Toleransi runout runner dan ketegak lurusan casing yang ingin di capai

Setelah mengidentifikasi kebutuhan dengan menghasilkan daftar tuntutan, selanjutnya mencari konsep rancangan yang mengacu kepada daftar tuntutan tersebut, dengan menentukan abstraksi fungsi keseluruhan dan fungsi bagian dari produk.

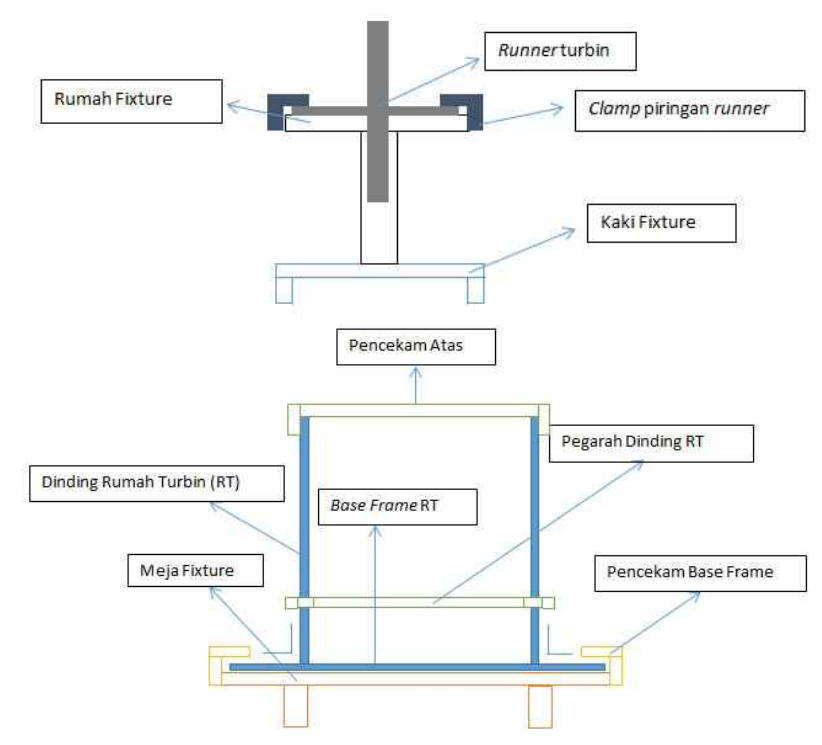

Gambar 2. Gambaran Konsep Rancangan Fixture runner dan Fixture casing

Fungsi bagian yang telah ditentukan selanjutnya didefinisikan sehingga menghasilkan beberapa alternatif fungsi bagian, lihat tabel 2 berikut: 
Tabel 3. Alternatif komponen fixture perakitan runner

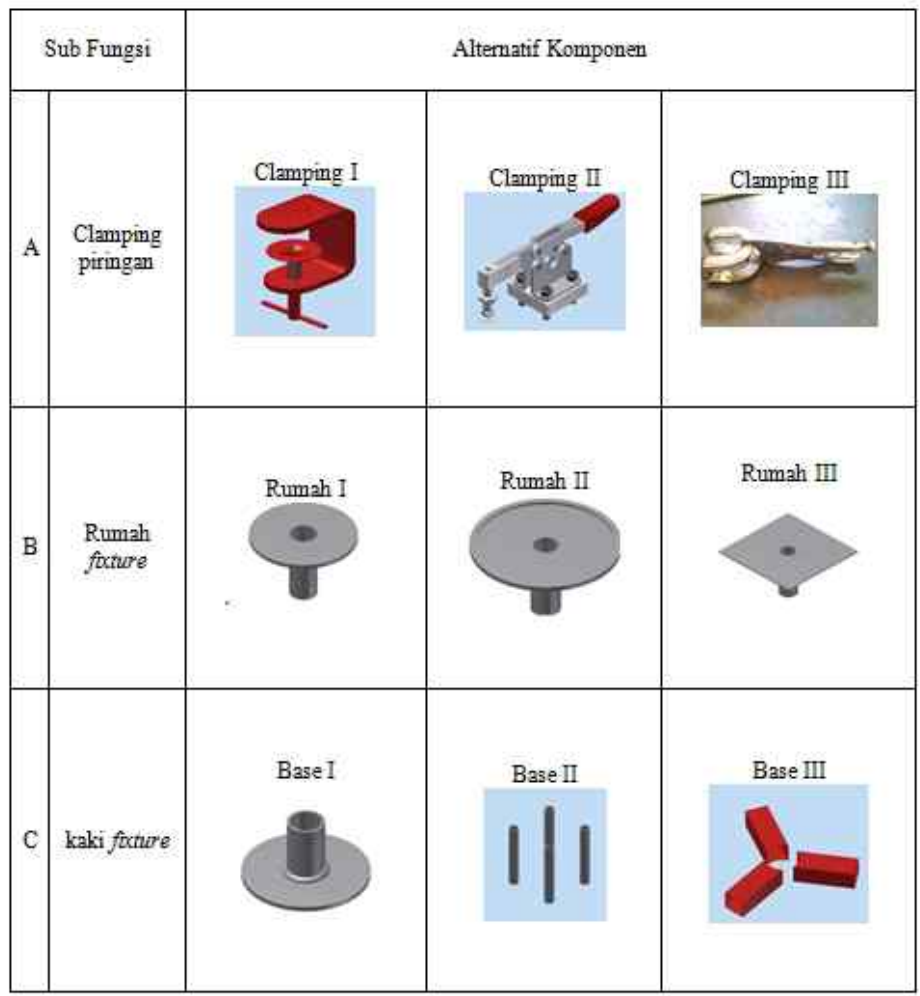

Hal yang sama dilakukan pada fungsi bagian fixture perakitan casing turbin cross flow yang masing-masing terdiri dari beberapa alternatif konsep. Setelah menentukan beberapa alternatif komponen setiap fungsi bagian, maka dilakukan evaluasi fungsi setiap alternative komponen dengan melakukan penilaian pada alternative komponen tiap bagian dengan metode EVAD, dalam metode ini, disusun suatu daftar evaluasi kriteria dan setiap kriteria distandarisasi menurut tujuan strategis, kemudian di susun nilai-nilai setiap kriteria, kemudian alternatif komponen dibandingkan secara kualitatif.

Tabel 4. Evaluasi alternatif komponen tiap fungsi

\begin{tabular}{|c|c|c|c|c|}
\hline Fungsi : & \multicolumn{4}{|c|}{ - Menjepit Benda Kerja } \\
\hline Tuntutan Fungsi: & \multicolumn{4}{|c|}{$\begin{array}{l}\text { Tidak mudah bergeser sa at operasi } \\
\text { Meminimalisir distorsi yang teja di pada } \\
\text { pirngan runner saat proses pengelasan }\end{array}$} \\
\hline \multirow{2}{*}{ Kriteria Penilaian } & \multirow[t]{2}{*}{ Standar } & \multicolumn{3}{|c|}{$\begin{array}{c}\text { Alternatif } \\
\text { Komponen }\end{array}$} \\
\hline & & I & II & III \\
\hline Kapasitas Daya Pencekaman & $\begin{array}{l}\text { Beagr }=3 \\
\text { Sedang }=2 \\
\text { Kecil =1 }\end{array}$ & 3 & 2 & 3 \\
\hline Kemudahan Pengoprasian & $\begin{array}{l}\text { Madah }=3 \\
\text { Sedang }=2 \\
\text { Sullit }=1\end{array}$ & 2 & 3 & 3 \\
\hline Biaya pembuatan pengadaan & $\begin{array}{l}\text { Murah }=3 \\
\text { Sedang }=2 \\
\text { Mahal }=1\end{array}$ & 2 & 1 & 2 \\
\hline Keterseidaandipasaran & 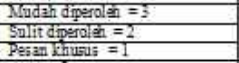 & 2 & 1 & 3 \\
\hline Waktu Set Up & $\begin{array}{l}\text { Cepat }=3 \\
\text { Sedang }=2 \\
\text { Lambar }=1\end{array}$ & 3 & 1 & 2 \\
\hline Kemudahanperawatan & $\begin{array}{l}\text { Madah }=3 \\
\text { Sodang }=2 \\
\text { Salit }=1\end{array}$ & 3 & 1 & 3 \\
\hline Kehandalan operasi & 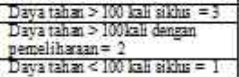 & 3 & 2 & 3 \\
\hline Total & & 18 & 11 & 19 \\
\hline
\end{tabular}


Hal yang sama dilakukan pada tiap-tiap fungsi bagian pada fixture perakitan runner dan casing turbin cross flow.

Dari hasil pemilihan komponen utama pada fixture perakitan runner, maka pemilihan rancangan assembly yang akan dikembangkan dan dibandingkan menjadi konsep rancangan assembly adalah alternatif komponen yang mendapatkan peringkat pertama (I) dan kedua (II) yang memiliki nila tertinggi yang ada pada tabel dibawah ini :

Tabel 5. Pemilihan Rancangan assembly

\begin{tabular}{|c|c|c|c|c|}
\hline \multirow{2}{*}{ Bagian Konsep } & \multicolumn{3}{|c|}{ Nilai Total Komponen } \\
\cline { 3 - 5 } & I & II & III \\
\hline A & Clamp piringan & $18_{0}$ & 11 & 19 \\
\hline B & Rumah Fixture & 13 & 9 & 12 \\
\hline C & Kaki Fixture & 13 & 11 & 12 \\
\hline
\end{tabular}

Berikut adalah beberapa alternatif variasi konsep pengembangan dari alternatif-alternatif komponen yang mendapatkan peringkat pertama dan kedua:
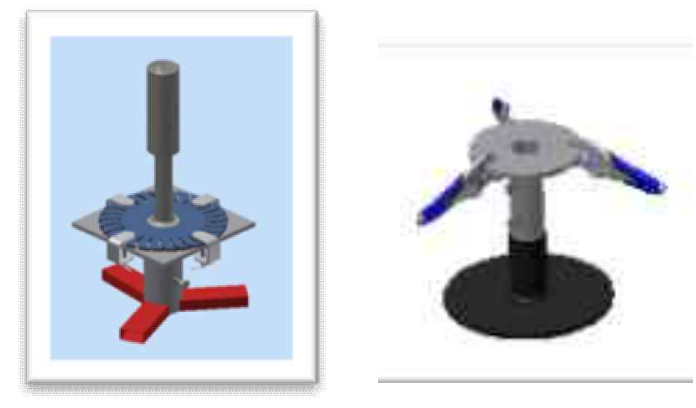

Gambar 3. Rancangan alternatif Assembly
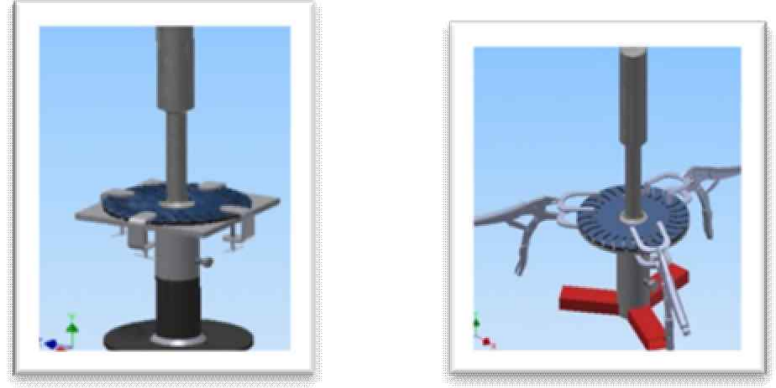

Hal yang sama juga dilakukan pada fixture perakitan casing turbin cross flow. Setelah dilakukan proses pemilihan rancagan dengan membandingkan setiap alternatif-alternatif konsep dengan kriteria yang telah di standarisasi. setelah setiap alternatif di bandingkan maka akan terpilih alternatif yang memiliki nilai tertinggi yang menjadi rancagan akhir dari alat bantu perakitan runner dan casing turbin. Kriteria yang distandarisasi ini dibuat berdasarkan data keinginan pengguna yang masuk dalam kriteria must and want. Adapun kriteria tersebut yaitu:

1. Kemudahan pengoprasian : Diharapakan dalam pengoprasianya semudah mungkin bagi si operator.

2. Keselamatan operator

3. Biaya produksi

4. Komponen standard

5. Tuntutan Tempat

6. Kemudahan Perawatan

7. Awet
: Alat harus aman bagi operator.

: Diharpkan biaya yang diperlukan untuk penyediaan komponen dan material seminimal mungkin.

: Diharapkan komponen yang digunakan mudah didapat di pasaran agar tidak kesulitan dalam penggantian komponen.

: Diharapkan alat bantu ini dapat di tempatkan di sembarang tempat.

: Diharapakan alat bantu ini mudah dalam perawatanaya agar alat tetap bekerja dengan baik.

: Diharapakan alat dapat bertahan dalam waktu yang lama sehingga mengurangi waktu perbaikan. 
Tabel 6. Pemilihan Alternatif rancangan assembly

\begin{tabular}{|c|c|c|c|c|c|c|c|}
\hline \multirow{2}{*}{ No } & \multirow{2}{*}{ Kriteria Penilaian } & \multirow{2}{*}{ Standar } & \multirow{2}{*}{ Nutlai } & \multicolumn{4}{|c|}{ Aiternatif Rancangan } \\
\hline & & & & 1 & II & III & IV \\
\hline \multirow{4}{*}{$\mathrm{E}$} & \multirow{4}{*}{$\begin{array}{l}\text { Kemudahan } \\
\text { pengoprasian }\end{array}$} & Seaze Shadzh & 3 & \multirow{4}{*}{3} & \multirow{4}{*}{2} & \multirow{4}{*}{1} & \multirow{4}{*}{2} \\
\hline & & Xsade & 2 & & & & \\
\hline & & Sodzas & $t$ & & & & \\
\hline & & Iatir & क & & & & \\
\hline \multirow{4}{*}{2} & \multirow{4}{*}{$\begin{array}{l}\text { Keselamatan } \\
\text { operator }\end{array}$} & $A=$ & 3 & \multirow{4}{*}{3} & \multirow{4}{*}{3} & \multirow{4}{*}{3} & \multirow{4}{*}{3} \\
\hline & & Kung $=$ & $\frac{1}{2}$ & & & & \\
\hline & & Bathakayz & $t$ & & & & \\
\hline & & Ienge thahay & o & & & & \\
\hline \multirow{4}{*}{3} & \multirow{4}{*}{ Biaya produksi } & Manh & 3 & \multirow{4}{*}{3} & \multirow{4}{*}{2} & \multirow{4}{*}{1} & \multirow{4}{*}{2} \\
\hline & & $\operatorname{sed}=3$ & 2 & & & & \\
\hline & & Xstat & $I$ & & & & \\
\hline & & $3=3=m x^{2} n$ & 9 & & & & \\
\hline \multirow{4}{*}{4} & \multirow{4}{*}{$\begin{array}{l}\text { Komponen } \\
\text { standard }\end{array}$} & $\operatorname{Adx}$ & 3 & \multirow{4}{*}{2} & \multirow{4}{*}{3} & \multirow{4}{*}{2} & \multirow{4}{*}{3.} \\
\hline & & Denze madifikar & $\frac{1}{2}$ & & & & \\
\hline & & 5a:4 & $i$ & & & & \\
\hline & & Digene & 0 & & & & \\
\hline & & $30 \mathrm{~b}=2$ & 3 & & & & \\
\hline 5 & Tuntritan tamnat & 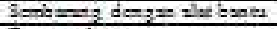 & 2 & 2 & 2 & 1 & 1 \\
\hline 2 & 1 untutan tempar & $\operatorname{Ten} y=d=$ & $I$ & & & & \\
\hline & & $\mathrm{Ien}=\mathrm{khaxux}$ & o & & & & \\
\hline & & 3engemads & 3 & & & & \\
\hline 6 & Kemudahan & 3udet & 2 & 2 & 3 & 3 & 2 \\
\hline 0 & perawatan & Zedaz & \pm & & & & \\
\hline & & Sitiat & 9 & & & & \\
\hline & & 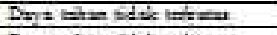 & 1 & & & & \\
\hline & & 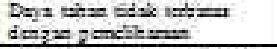 & 2 & & & & \\
\hline 7 & Awet & 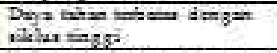 & \pm & 3 & 2 & 3 & 2 \\
\hline & & 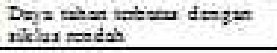 & a & & & & \\
\hline & & at sele & & 18 & 17 & 15 & 16 \\
\hline & & E.gkas & & 1 & 2 & 4 & 3 \\
\hline
\end{tabular}

Dari matrik pemilihan alternatif rancangan di atas, maka alternatif yang memiliki skor tertinggi adalah alternatif I, jadi alternatif tersebut yang akan dibuat menjadi rancangan akhir. Dari sketsa alternatif I maka dapat dikembangkan lagi dan disesuaikan dengan dimensi dari runner turbin yang akan dibuat pada alat bantu tersebut. Berikut ini alternatif I yang akan dibuat menjadi rancangan akhir.

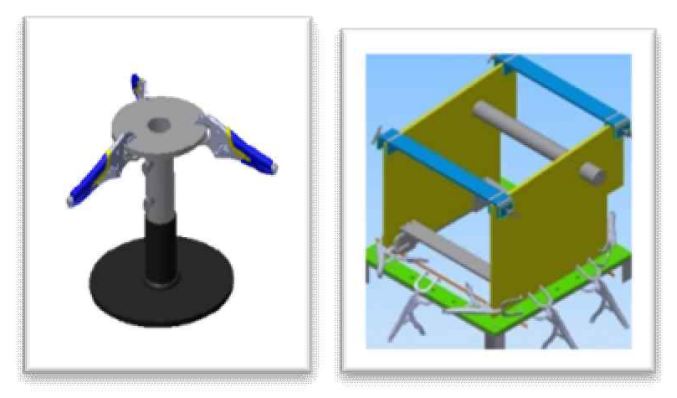

Gambar 4. Rancangan akhir Fixture Perakitan Runner dan fixture perakitan Casing turbin

\section{B. Perencanaan Produksi}

Perencanaan produksi berawal dari penentuan urutan pengerjaan pada masing-masing komponen fixture, kemudian penentuan mesin perkakas dan perkakas bantu yang digunakan. Pada subbab selanjutnya juga akan dijelaskan mengenai pembuatan program NC yang ditujukan pada pengerjaan komponen-komponen presisi dengan mesin CNC. Sistem fixture hasil perancangan terdapat komponen-komponen standar yang di pesan dan ada komponen-komponen yang diproduksi sendiri. Total komponen dan baut yang dibreakdown dan ditampilkan dalam tabel 8. berikut ini. 
Tabel 7. Breakdown komponen fixture

\begin{tabular}{|c|c|c|}
\hline No. & Nama Komponen fixture runner & Jumlah \\
\hline 1 & Clamp piringan (pesan) & 3 \\
\hline 2 & Rumah Fixture nunner & 2 \\
\hline 3 & Meja (pesan) & 1 \\
\hline 4 & Kaki fuxture runner & 1 \\
\hline 5 & Baut Ml2 (pesan) & 4 \\
\hline No. & Nama Komponen fxturs casing & jumlah \\
\hline 1 & Clamp dinding Atas & 2 \\
\hline 2 & Poros dinding & 1 \\
\hline 3 & Pengarah dinding RT (pesan) & 4 \\
\hline 4 & Clamp Base Frame RI (pesan) & 4 \\
\hline 5 & Meja Fixture Casing & 1 \\
\hline 6 & Baut M6 (pesan) & 16 \\
\hline 7 & Baut M12 (pesan) & 4 \\
\hline 8 & Pin Dia 12 mm & 8 \\
\hline
\end{tabular}

Komponen-komponen yang di pesan merupakan komponen-komponen standard dan komponen yang belum mampu di produksi di dalam bengkel sehingga dilakukan pemesanan di luar bengkel dan adappun komponen yang bukan standard dan mampu di produksi di bengkel maka di lakukan proses produksi pada bengkel tersebut. Setelah komponen-komponen dibuat, kemudian dilakukan pengukuran sesuai dengan toleransi geometris yang ingin di capai.
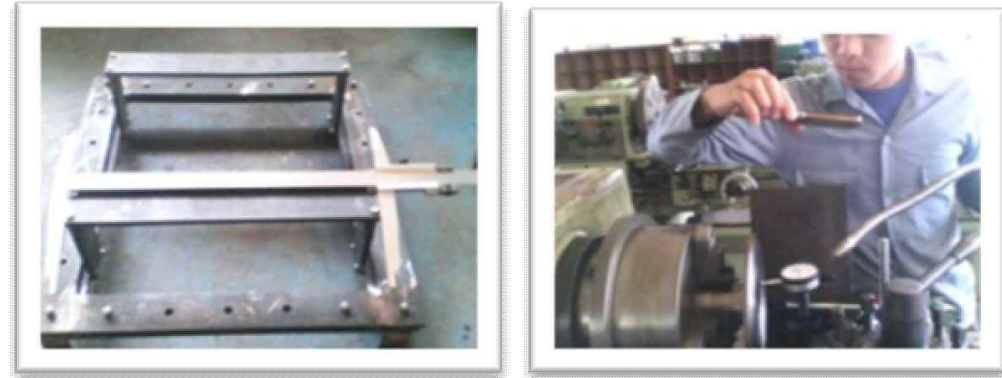

Gambar 5. Proses pengukuran Fixture

Proses pengukuran komponen-komponen yang dibuat dilakukan untuk mengetahui dimensi dari produk yang dibuat apakah sesuai toleransi geometris yang di tentukan dalam gambar kerja atau tidak. Setelah proses pengukuran komponen-komponen fixture kemudian dilakukan proses assembly pada setiap komponen yang di pesan dan di buat.
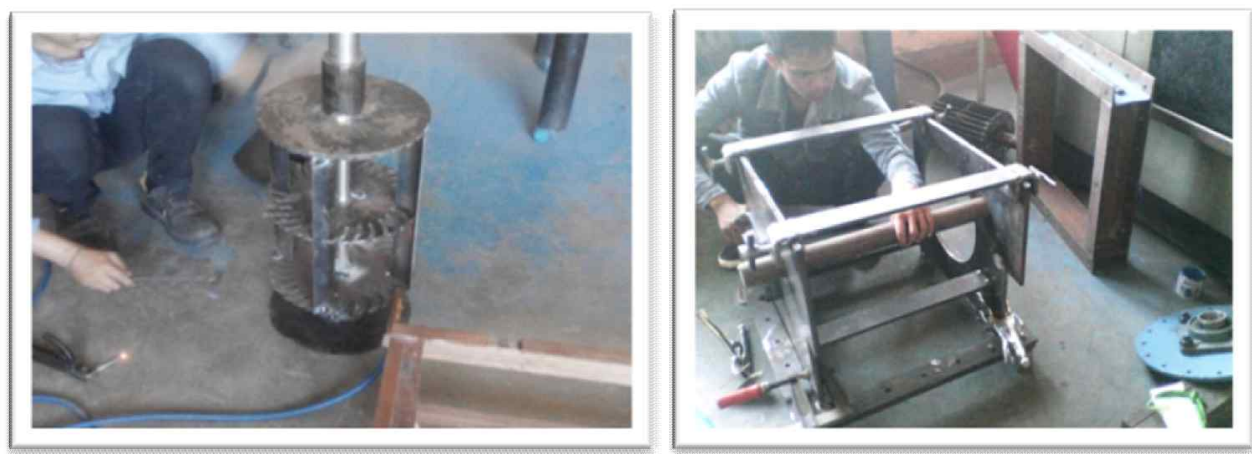

Gambar 6. Proses assembly kompo 


\section{HASIL DAN PEMBAHASAN}

\section{A. Parameter Kualitas Fixture}

Nilai penyimpangan pada fixture sangat berpengaruh pada hasil dari benda kerja yang di hasilkan , makin tinggi kepresisian fixture dan sistem pencekaman yang di buat maka potensi penyimapangan yang akan terjadi pada produk akan semakin kecil. Nilai toleransi yang didapatkan pada fixture setelah di lakukan pengukuran adalah untuk fixture perakitan runner sebesar ${ }^{+}-0.5$ sedangkan untuk fixture casing ${ }^{+}-0.3$.

\section{B. Pengujian}

Pengujian ini dilakukan dengan cara membuat runner dan casing turbin menggunakan fixture perakitan runner dan casing untuk mengetahui penyimpangan produk yang di hasilkan dari perakitan produk dengan menggunakan alata bantu yang telah di buat. Pengukuran runner dilakukan pada setiap sidenya dengan menggunakan dial indikator yang di lakukan pada mesin bubut. Sedangkan pengukuran pada casing dilakukan pada mesin $\mathrm{CNC}$ mill dengan menggunkan instrumen alat ukur berupa dial indikator.

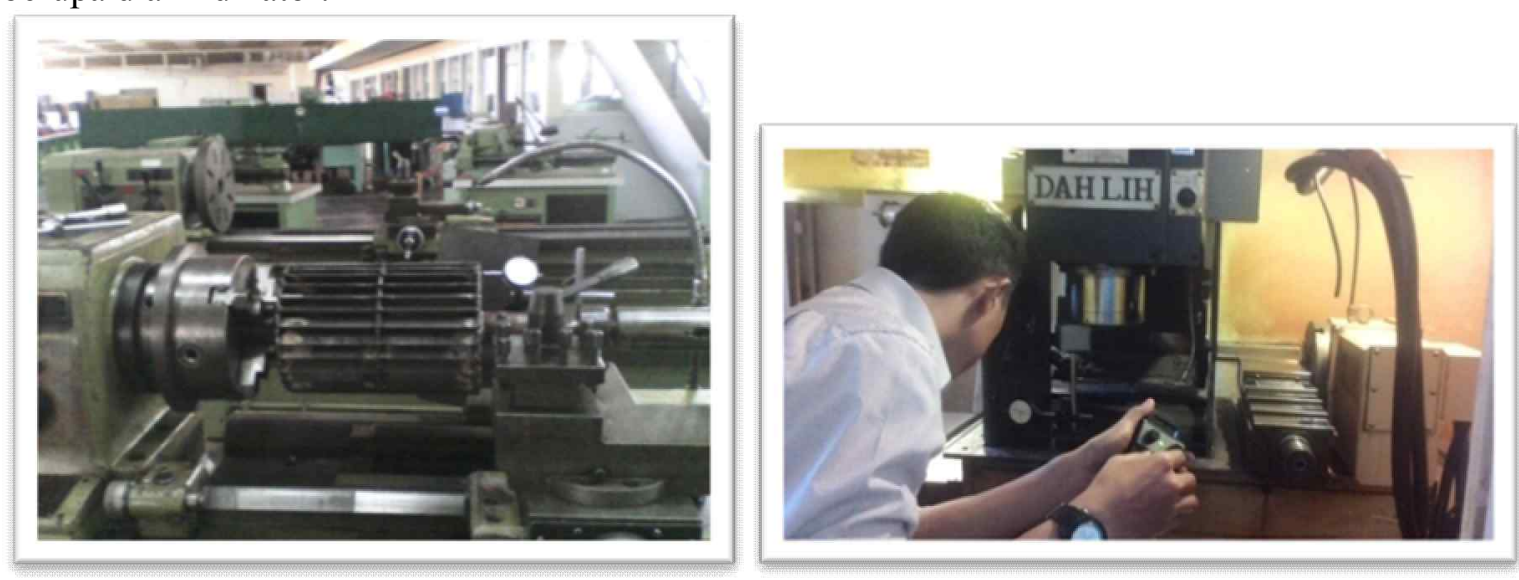

Gambar 7. Proses pengukuran produk yang di hasilkan dari alat bantu

\section{Hasil Pengujian Fixture Perakitan Runner Turbin}

Pembuatan runner turbin menggunakan fixture perakitan runner telah berhasil dilakukan sesuai dengan prosedur perakitan yang telah di tentukan dan telah berhasil menurunkan penyimpangan putar (runout) pada pembuatan runner turbin. Kemudian benda uji diukur sesuai dengan kriteria kualitas yang telah ditentukan. Kemudian data tersebut digunakan untuk megetahui apakah runner yang di hasilkan dengan menggunakan alat bantu fixture perakitan runner mampu memenuhi target rancangan yang ingin di capai, berikut hasil pengukuran penyimpangan putar (runout) pada hasil perakitan runner dengan dan tanpa alat bantu. Tabel 8. memperlihatkan hasil pengukuran runout kedua sisi benda uji runner turbin cross-flow dengan dan tanpa alat bantu;

Tabel 8. Hasil Pengukuran Runner turbin dengan dan tanpa alat bantu

\begin{tabular}{|c|c|c|c|}
\hline Sisi Pengukuran & $\begin{array}{c}\text { Penyimpangan } \\
\text { Minimum }(\mathrm{mm})\end{array}$ & $\begin{array}{c}\text { Peny. Dengan Alat Bantu } \\
(\mathrm{mm})\end{array}$ & $\begin{array}{c}\text { Peny. Tanpa Alat Bantu } \\
(\mathrm{mm})\end{array}$ \\
\cline { 1 - 3 } Side A & \multirow{2}{*}{1.0} & 1.9 & 3.0 \\
\cline { 1 - 3 } Side B & & 1.8 & 3.2 \\
\hline
\end{tabular}

Berdasarkan hasil pengukuran diatas dapat dilihat bahwa penyimpangan yang terjadi pada runner turbin dengan menggunakan alat bantu menghasilkan penyimapangan sebesar 1.8-1.9 mm, nilai ini lebih kecil dibandingakan penyimpangan yang terjadi pada runner tanpa menggunakan alat bantu yaitu 3.0-3.2 mm sehingga dapat di simpulkan bahwa fixture ini sudah mampu menurunkan penyimpangan 
yang terjadi pada runner meskipun nilai yang di hasilkan belum mampu memenuhi target penyimpangan yang ingin di capai yaitu $1.0 \mathrm{~mm}$.

\section{Hasil Pengujian Fixture Perakitan Casing Turbin}

Pengukuran ketegak lurusan casing dilakukan pada mesin CNC Mill untuk mengetahui penyimpangan ketegak lurusan yang terjadi pada dinding-dinding casing setelah pengelasan, dan untuk mengetahui apakah penyimpangan geometri dari dinding-dinding casing sudah memenuhi target tuntutan rancangan yang ingin dicapai yaitu $1.0 \mathrm{~mm}$. Pengukuran dilakukan pada titik A, B, dan C pada setiap dinding. Tabel 9 memperlihatkan penyimpangan geometri dinding casing terhadap datum (base frame).

Tabel 9. Hasil Pengukuran ketegaklurusan casing turbin

\begin{tabular}{|c|c|c|c|}
\hline $\begin{array}{c}\text { Sisi. } \\
\text { Pengukuran }\end{array}$ & $\begin{array}{c}\text { Titil } \\
\text { Pengulzuran }\end{array}$ & $\begin{array}{l}\text { Renyimpangan } \\
\text { Minimum } \\
\text { (mm) }\end{array}$ & $\begin{array}{l}\text { Renyimpangan } \\
\text { Altual (mm) }\end{array}$ \\
\hline \multirow{3}{*}{ Dinding A } & A & \multirow{3}{*}{$1.0 \mathrm{~mm}$} & 1.25 \\
\hline & $B$ & & 1.20 \\
\hline & C & & 1.60 \\
\hline \multirow{3}{*}{ Dinding B } & $\mathrm{A}$ & \multirow{3}{*}{$1.0 \mathrm{~mm}$} & 0.45 \\
\hline & B & & 0.73 \\
\hline & $\mathrm{C}$ & & 0.85 \\
\hline
\end{tabular}

Berdasarkan hasil pengukuran diatas, nilai penyimpangan yang terjadi pada kedua dinding berbeda dimana dinding A menghasilkan penyimpangan terbesar yaitu $1.60 \mathrm{~mm}$ dari penyimpangan yang diijinkan yaitu $1.0 \mathrm{~mm}$, sedangkan penyimpangan yang dihasilkan dari dinding $\mathrm{B}$ yang paling besar terjadi pada titik C yaitu $0.85 \mathrm{~mm}$ dibawah batas toleransi yang telah di tentukan. Nilai penyimpangan yang terjadi pada dinding A yang keluar dari batas toleransi yang telah ditentukan dikarenakan proses pengelasan dinding-dinding tidak bersamaan dilakukan di kedua sisi yang menyebabkan deformasi yang terjadi pada dinding yang sedang dilas ikut mempengaruhi dinding yang satunya.

Berdasarkan hasil pengujian menggunakan fixture perakitan casing dan pengukuran yang dilakukan pada hasil Perakitan casing turbin cross-flow menggunakan fixture perakitan casing, dapat di simpulkan bahwa fixture perakitan casing belum mampu untuk memenuhi target penyimpangan toleransi geometris yang ingin di capai $(1.0 \mathrm{~mm})$.

\section{KESIMPULAN}

Penggunaan fixture belum memenuhi target yang telah di tentukan (toleransi runout $1.0 \mathrm{~mm}$ ) pada runner dan (toleransi ketegak lurusan $1.0 \mathrm{~mm}$ ) pada casing yang dihasilkan, namun pada umumnya penggunaan fixture perakitan runner dan casing turbin berjalan dengan baik dan mampu memperkecil penyimpangan putar (runout) pada runner, dan dimensi pada casing turbin cross flow.

\section{DAFTAR PUSTAKA}

[1] Hoffman, Edward G. 1996Jig and Fixture Design.Fourth Edition. Delmar Publisher. (Online),(https://books.google.co.iddiakses 16 November 2014).

[2] Ibrahim, Coco.1986. "Perkakas Bantu". Laboratorium Teknik Produksi dan Metrologi Industri. Bandung:Jurusan Mesin ITB.

[3] Jones, Franklin. D. 1955Jig and Fixture Design.Fourth Edition. The Industrial Press. New York.(Online), (https://books.google.co.iddiakses 10 November 2014).

[4] Kurniawan. 2000. Perencanaan Peralatan Penepat. Bandung:Polman. 
[5] Listianto. 2012. "Perbandingan Kaizen Jig Locator Mesin Muratec Mw 120 untuk Mendeteksi Miring Pada Part Gear Kph M4". Laporan Tugas Akhir. Karawang: Sekolah Tinggi Teknologi Texmaco.

[6] Makhrani. 2013. "Survey Potensi Mikrohidro Aliran Irigasi untuk Memenuhi Kebutuhan Listrik Masyarakat Pedesaan di Sulawesi Selatan” Dalam Majalah Ilmiah Al-Jibra, Vol XIV (47). Makassar: Universitas Hasanuddin.

[7] Prasetiyo. dkk. 2010. "Rancangan Jig dan Fixture untuk Proses Produksi Gear Belakang Sepeda Motor Yamaha". Dalam Procedding Seminar Nasional IV Manajemen \& Rkayasa Kualitas, Jurusan Teknik dan Manajemen Industri Institut Teknologi Nasional.

[8] Susilawati, Anita. dkk. 2006. "Perancangan Modular Fixture untuk Proses Freis, Milling dan Sekrap". Dalam Jurnal Teknik Mesin, Vol3.No2. Riau.

[9] Harsokoesoemo, D., 2004, Pengantar Perancangan Teknik, Penerbit ITB, Bandung.

[10] Takeshi Sato. 1992. Menggambar Mesin Menurut Standard ISO. Jakarta:PT. Pradiyana Paramita. 